\title{
Different Participant Groups, Different Success Definitions: An Exploratory Study in the Case of "Local Government and NGO Cooperation in a Participatory Democracy Project"*
}

\author{
Neslihan Kulözü** \\ Atatürk University
}

\begin{abstract}
In the development of participatory approaches, evaluations of the participatory practices have been increasingly discussed due to the different conceptualizations of participation: whether it was a means to an end, or an end in itself. On the other hand, regardless of the conceptualizations of participation, there has been a tendency to evaluate participatory practices using pre-defined criteria of success. However, the present study argues that each participatory practice should be evaluated by all of its participants by developing a shared understanding and agreed-upon criteria of success, since such an evaluation process should take into account the uniqueness of each locality and each participatory practice, and the participation right of the individual in the evaluation process. As such, to reveal the requirements for the individual evaluation of each participatory experience, this study aims to explore the differences between the success definitions of different participant groups from contextually different settings in Turkey: Gazi (Samsun), Kaymaklı (Nevşehir), Odunpazarı (Eskişehir) and Seyrek (İzmir), which have the same project objectives as partners in the Local Government and NGO Cooperation in the Participatory Democracy project. For this exploratory case study, in-depth interviews were conducted with participants from four localities covered in the case project to obtain subjective descriptions of their definitions of success. At the end, the study has revealed that the respondents from each locality defined success in different ways, including, but not confined to attributes of the "process," "end products," "personal," "interpersonal" and "cultural-contextual" content groups. Moreover, success definition of the participant groups revealed that they conceptualized participation either as an end in itself or both as a means to an end and as an end in itself. Additionally, this study explored the relationship between the socio-economic development levels of localities and the definitions of success of the participant groups in these localities.
\end{abstract}

Keywords: participatory practice, participation as a means to an end, participation as an end in itself, success definition, success attributes.

Acknowledgement: I am grateful to all who took part in these initiatives and agreed to be interviewed as part of this study and to Professor İlhan Tekeli who helped me during the preparation of this study.

* This article is derived from the author's Ph.D. Thesis (Kulözü, 2012) entitled "Socio-Psychological Dimensions of the Participatory Processes: In the Case of the Local Government and NGO Cooperation in Participatory Democracy Project," which received the "2011-2012 Best Thesis of the Year Award" at Middle East Technical University.

** Neslihan Kulözü is an Assistant Professor in the Department of City and Regional Planning at Atatürk University, Erzurum, Turkey. E-mail.nkulozu@atauni.edu.tr 


\section{Farklı Katılımcı Grupları, Farklı Başarı Tanımları: Katılımcı Demokraside Yerel Yönetim ve STK İşbirliği Projesi Örneğinde Keşfetmeye Dayalı Bir Çalışma}

\section{Özet}

Katılımlı yaklaşımların gelişimi içinde, katılımlı pratiklerin başarısının nasıl değerlendirilebileceği tartışması, katılımın araç ya da amaç olarak kavramsallaştırılmasına bağlı olarak devam etmektedir. Diğer taraftan ise literatürde, katılımının nasıl kavramsallaştırıldığından bağımsız olarak, katılımlı pratiklerin önceden belirlenmiş başarı kriterleri ile değerlendirilmesi eğilimi yaygınlık göstermektedir. Bu çalışmada ise her bir katılımlı pratiğin kendi katılımcıları tarafından geliştirilen ve üzerinde uzlaşılmış başarı kriterleri ile değerlendirilmesinin gerekliliği vurgulanmaktadır. Çünkü ancak böyle bir değerlendirme ile her bir yerelin ve dolayısıyla her bir katılımlı deneyimin özgünlüğü dikkate alınarak, katılımcıların değerlendirilme sürecine katılma hakları gerçekleştirilebilir. Bu nedenle çalışmada, katılımlı deneyimlerin özgün bir biçimde değerlendirilmesinin gerekliliğini ortaya koymak için 'Katılımcı Demokrasi'de Yerel Yönetim ve STK İşbirliği Projesine' Türkiye'nin farklı bağlamsal özelliklerine sahip yerellerinden katılmış grupların başarı tanımlamaları arasındaki farklılıkların keşfedilmesi amaçlanmıştır. Çalışmada örmek olarak seçilen katılımlı projenin ortağı olarak aynı amaçla katılımlı süreçleri yürüten ve bu çalışmaya konu olan yereller Gazi (Samsun), Kaymaklı (Nevşehir), Odunpazarı (Eskişehir) ve Seyrek (İzmir)'dir. Keşfetmeye dayalı bu çalışma kapsamında, projenin ortağı her bir yerelde gerçekleşen katılımlı sürecin katılımcıları ile başarı tanımlamalarına ilişkin öznel tanımlamalarını almak üzere derinlemesine görüşmeler yapılmıştır. Bu çalışma sonucunda farklı bağlamlardan her bir grubun katılımlı deneyimin başarısını farklı şekilde tanımladığı, tanımlamaları sırasında aynı düzeyde olmamakla birlikte süreç, süreç çıktıları, birey, bireylerarası ve kültürel-bağlam içerik gruplarında yer alan özellikleri kullandıkları görülmüştür. Katılımlı pratiğin başarısını farklı şekilde tanımlayan grupların tanımlamaları onların katılımı amaç veya hem amaç hem araç olarak kavramsallaştırdıklarını göstermiştir. Ayrıca, araştırmanın sonucunda çalışmaya konu olan yerellerin sosyo-ekonomik gelişmişlik düzeyi ile katılımlı pratikler için yaptıkları başarı tanımları arasında bir ilişki olduğu ortaya koyulmuştur.

Anahtar kelimeler: katılımlı pratik, araç olarak katılım, amaç olarak katılım, başarı tanımı, başarı nitelikleri.

I $\mathrm{n}$ the development of participatory approaches over the last decade of the 20th century, evaluations of participatory experiences were being increasingly discussed; however, while there continues to be much discussion, there remains little consensus on how success should be appraised due to the different conceptualizations of participation: whether it is a means to an end, or an end in itself. These conflicting concepts necessitate different ways of evaluating participatory practices and their success. Regardless of whether participation is conceptualized as a means to an end or as an end in itself, 
there is a tendency to evaluate participatory practices using pre-defined criteria of success; however there are key differences between the ways these criteria are determined.

This study reveals that there are two main ways in which criteria of success are determined for participatory practices in the participation literature. Following one line of debate in literature, this study claims that a participatory practice should be evaluated by all of its participants, since each participant group will define success differently relative to their participation conceptualization and their own expectations from the project or decision making process, even when they are partners in the same participatory experience. In short, the present study argues that every participatory practice by nature is unique, and so needs to be evaluated as such by its all participants through developing a shared understanding and agreed-upon criteria of success.

Building on this argument, the present study aims to explore the success attributes and differences between the definitions of success provided by each participant group from four different contextual settings in Turkey: Gazi (Samsun), Kaymaklı (Nevşehir), Odunpazarı (Eskişehir) and Seyrek (İzmir) as partners in the Local Government and NGO Cooperation in the Participatory Democracy project. The participants' individual definitions will reveal how the participant groups will evaluate the success of participatory practice in relation to how they conceptualize participation. Therefore, through the definitions of success of contextually different participant groups, the present study will also explore how they conceptualize participation: as a means to an end or as an end in itself.

To achieve its aim, this study was designed as a case study and was planned to pursue an exploratory research approach. However, the limitations of the present study are confined to the selected case study. To focus on the evaluations of success of different participant groups, a multi-partner participatory project was selected for study. This ensured that there were no inaccuracies in the results related to different objectives of different projects and it allowed the effects of contextual differences on the definitions of success to be highlighted. That said, in each case the participant numbers were different depending on the locality, and as a result, the number of respondents interviewed during the field study were also different. In the present study, this limitation has been addressed by presenting the quantitative results of the content analysis in each case as an "average per person."

In this study, first the participation and participatory practices and the discussions related to their success are presented; after that the Local Government and NGO Cooperation in the Participatory Democracy project is introduced as the focus project of this study, with a presentation of the case study areas in which the project is being applied being Gazi, Kaymaklı, Odunpazarı and Seyrek to allow an understanding of their contextual characteristics. Third, the methodology of the research, being the analytical procedure used to explore the attributes of success, is introduced, after which the findings of the study are presented in two parts: first, the findings for the case project obtained from the total sample, and second, the findings for each of the individual participant groups. Finally, the findings of this exploratory case study are interpreted and research proposals for further studies are presented. 


\section{Participatory Practice and Its Success}

Participation refers to the direct involvement of the public in decision-making processes through a range of formal and informal mechanisms. As proponents of participation and participatory practices, Wondolleck and Yaffee (2000) argue that participation leads to better decisions; and similarly, Fung and Wright (2001) state that participation can lead to effective and equitable solutions while increasing the capacity of the public for self-governance. Participatory approaches are discussed as being more democratically accountable than traditional, representative and instrumental approaches. Opposing the instrumental approaches, as stated by Cooke and Kothari (2001), the ostensible aim of participatory approaches is to make people more central to development by encouraging beneficiary involvement in interventions that affect them and over which they previously had only limited control or influence.

Global trends toward participation and participatory practices began to appear in both literature and practice in the second half of the $20^{\text {th }}$ century. The concept of participation has attracted researchers from a broad range of academic disciplines, such as public management, planning, political science, educational science and sociology. Under the effect of this global tendency, focus has shifted from outputs, such as plans and/or policies, to participatory processes in the field such as planning, public management and political sciences. As a result, participatory practices have started to be conceptualized as processes that are instigated by the participants and their interactions within a unique context (Kulözü and Tekeli, 2014).

In parallel to the growth of participatory practices, the literature which has discussed their evaluation has also witnessed an increase, beginning at the end of the $20^{\text {th }}$ century; however consensus has not yet been reached on how to define success, nor even the methods of evaluation. The lack of knowledge and consensus on the success of participatory practices could be related to its complexity; however regardless of its complexity, it is necessary to answer the question of how participatory practices may be evaluated to see whether they achieve a sufficient level of success, and based on the answer, to develop ways to improve those levels. To allow an evaluation of participatory practices, it is first necessary to define what is meant by success in this regard, which would reveal also what is expected; however there is not even consensus on the terms used to refer to success, nor the way they may be used to evaluate participatory practices.

The terms which are used to refer the success of participation and participatory practices, and are commonly used to define success (Buchy and Hoverman, 2000; Chess and Purcell, 1999; Innes and Booher, 1999; Koontz and Thomas, 2006), are effectiveness (Rosener, 1978), efficiency (Brand and Gaffikin, 2007), and equity (Fung and Wright, 2001). While effectiveness refers to the ratio of targets set to outputs achieved, efficiency refers to the ratio of inputs to outputs. Equity, on the other hand, means ensuring actions do not affect some less favorably than others. Although some scholars use just one of these terms to define the success of participatory practices, Warburton (1997) argues that all three concepts should be employed (cited in Buchy and Hoverman, 2000). Following Warburton (1997), Coglianese (2002) argues that when evaluating the success 
of participatory practice, researchers should focus on the effectiveness, efficiency and equity of the decisions made during the participatory process.

In addition to the lack of consensus on terminology, there has also been a lack of consensus on how to evaluate success. This situation may arise from the different approaches used by researchers to conceptualize participation in participatory practices. In previous literature (Arnstein, 1969; Tekeli, 1990; Pretty, 1995; White, 1996; Kulözü, 2011), different conceptualizations of participation have been discussed based on the participatory experiences in which the levels of participation show differences. The different conceptualizations of participation produce different ways of evaluating participatory practices and their successes. Even though all scholars conceptualize the level of participation in different ways, as discussed by Rosener (1978) in relation with the discussion on success, participation can be conceptualized first as a means to an end, and second as an end in itself. While the former considers participation as a tool for increasing the quality of end products and the legitimacy of a participatory (decision/ plan-making) process, the latter accepts it as a democratic human right of those who will be affected by decisions and/or actions arising from the process, leading to a shift in the focus of participatory practices from product to process.

In addition to the evaluation of participatory practices following the two approaches discussed thus far, a combination of these approaches, referred to by Chess and Purcell (1999) as the middle ground, requires finding a balance between the goals of both approaches. In this case, the criteria of only one approach to participation will not be sufficient for an evaluation of the success of a participatory practice. Although the present study argues that participation should be conceptualized as an end in itself as a democratic human right, this does not apply to some participatory practices, such as participatory planning experiences. In such cases, the aim of participatory practice is also to intervene in the spatial environment, which should also focus on end products. Therefore, even though the present study positions itself close to the body of literature conceptualizing participation as an end in itself, in some cases the middle ground, as discussed by Chess and Purcell (1999), could be accepted. Such an approach is especially important for participatory practices in which the process and the end results are not mutually exclusive, and where focusing on one does not constitute a rejection of the other.

In short, the evaluation ways of participatory practices reveal that the evaluation methods and then evaluation itself show differences depending on whether participation is conceptualized as an end in itself or as a means to an end. While the success of participatory practices as a means to an end is evaluated in terms of outputs, in other words tangible items such as a plan, project, decision, and policy, the success of participatory practices as an end in itself is evaluated mainly in terms of the participatory process. However, there is even a difference of opinion on the evaluation to be carried out that depends on the conceptualization of participation, and whether it is conceptualized, it as an end in itself, or as a means to an end; regardless, there is a tendency to evaluate participatory practices using pre-defined criteria of success.

This study found that the scholars and their studies to determine success criteria can be categorized into two groups: those who derived the success criteria from theoretical 
discussions (such as Crosby, Kelly and Schaefer, 1986; Rowe and Frewer, 2000; Cooper, 2002; Rowe et al., 2004; Dowling et. al., 2004), and those who defined success criteria from their own case/empirical studies. The second group can be further categorized into two groups: first, those who determine these criteria through consultations with the participants (Carnes et al., 1998; McCool and Guthrie, 2001; Shindler and Neburka, 1997; Tuler and Webler, 1999; Webler and Tuler, 2000, 2001, 2002, 2006; Webler et al., 2003; Mascarenhas and Scarce, 2004; Dalton, 2006), and those who define these criteria by asking the experts and/or managers taking part in the participatory experience (Tuler et al., 2002; Mostert et al., 2007).

Among the first group of scholars, some categorized the success criteria in two groups, acceptance criteria and process criteria (Rowe and Frewer, 2000; Cooper, 2002; Rowe et al., 2004). While acceptance criteria refers to features of a method that make it acceptable to the wider public, the process criteria refers to features of the process that are liable to ensure that it takes place in an effective manner. The authors discuss the representativeness, independence, early involvement, influence and transparency as acceptance criteria which are related to the effective construction and implementation of a procedure. On the other hand, among the first part of the second group of scholars who determine these criteria through consultations with the participants, Tuler and Webler (1999), Webler and Tuler $(2000,2001,2002,2006)$ and Webler et al. (2003) mainly focus on the success criteria of the process rather than products of the process. As an example of this approach, Tuler and Webler (1999) defined seven principles: access to the process; power to influence process and outcomes; access to information; structural characteristics to promote constructive interactions; facilitation of constructive personal behaviors; adequate analysis; and enabling of future processes. Last, among the other part of the second group scholars who define these criteria by asking the experts and/or managers taking part in the participatory experience, Tuler et al. (2002) designed the qualitative analysis of open-ended interviews with local government officials from three different cases. As a result of the study, nine criteria were explored: efficacy and progress, preferences for a participatory experience, clear objectives, estuary project support and resources, personal values, past experiences, time, municipal support and resources, and socio-political context.

Following one line of debate in the literature, the present study argues that the success of participatory practices should be evaluated using criteria that are developed by the participants themselves for each unique participatory practice. Evaluating the success of participatory practices using only one's own success criteria, or based on criteria sourced from literature alone ignores the uniqueness of each locality, and hence any evaluation may not clearly capture the unique context-dependency of a participatory practice. With its argument related to the determination of success criteria, the present study is positioned close to that of Buchy and Hoverman (2000) who developed two means of evaluating success that included developing a shared understanding of success as well as a monitoring and evaluation process that used criteria previously agreed upon by the stakeholders. Instead of determining a standard set of success criteria, Buchy and Hoverman (2000) proposed a means of defining the success criteria that emphasized both the importance of participation in the evaluation process and the development of a 
shared meaning during the evaluation process. By determining the criteria in this way, the uniqueness of each context and participatory practice which require locally-invented success criteria are also taken into account.

To reveal the uniqueness of the definition of success of different participant groups and hence the need to evaluate each participatory experience uniquely, this study intends to explore how success is defined by the participant groups in a single project that is being applied in contextually different settings in Turkey that have the same project objectives.

\section{Case Study: The Local Government and NGO Cooperation in Participatory Democracy Project}

In Turkey, the legal infrastructure that allows local administrations to create city councils and NGOs to participate actively in local decision-making mechanisms was passed into law by the Grand National Assembly with the enactment of the Local Administrations Code (No: 5355, ratified on 26.05.2005). With this legal arrangement, the participation of civil organizations (universities, occupational organizations and NGOs) in local councils was made possible, allowing members of the public to participate as active citizens in the administration of the city in which they live. However, in practice there are serious concerns and shortfalls that can mostly be explained by the lack of experience in participatory administration in the country. To respond to the need to launch an initiative that would serve as a guide in this issue (STGM, 2005), the Local Government and NGO Cooperation in the Participatory Democracy Project was designed by the Civil Society Development Center (in Turkish Sivil Toplum Geliştirme Merkezi, referred to hereafter as the STGM) with the purpose of enabling local administrations to create participatory administration structures in cooperation with the NGOs in their area.

The STGM, the initiator of the case project, was founded on 20 April, 2004 with the vision of creating a strong and democratic civil society. ${ }^{[1]}$ In line with this vision the Local Government and NGO Cooperation in the Participatory Democracy Project was designed and implemented with support from the European Commission (STGM, 2005). The project was launched with the participation of five local municipalities in Turkey: Gazi, Kaymaklı, Kızıltepe, Odunpazarı and Seyrek and the NGOs in these localities, and ran from September 2005 until April 2007. As part of the project, STGM organized three main meetings during which the partner localities came together to share their experiences within their participatory processes, and provide technical and educational support for each locality in their own contexts for the duration of the project process. ${ }^{[2]}$ In the interim periods between these meetings, each participant locality worked to create

[1] To reach this vision, STGM aims to ensure the development of participation and democracy in civil society, to strengthen organizational capacity and autonomy, and to make the voice of civil society heard in decision making processes (STGM, accessed: March 30, 2012, url: http://stgm.org.tr).

[2] The first meeting was organized in Beyoğlu (İstanbul) on 25-26 November, 2005; the second was organized in Kaymaklı (Nevşehir) on 20-22 June, 2006; and the third in Kız1ltepe (Mardin) on 25-26 December, 2006. STGM requested the participation of seven personnel from each partner locality at these meetings, including municipality mayors and NGO representatives who are considered to be the main stakeholders in the project process. 
participatory administration structures with the support of STGM to make a shift from management to participatory decision-making processes. Even though the objective of the process was the same for each case locality, differences emerged in both the participatory processes of the partner localities and in their end products. The participatory project was conducted in five localities of Turkey, and empirical data was collected from four of them (Gazi, Kaymakl1, Odunpazarı and Seyrek) (Table 1).

\section{Contextual Differences of the Case Areas: Gazi, Kaymaklı, Odunpazarı and Seyrek}

The case study areas are Gazi Municipality within the District of Samsun in the Black Sea Region, Kaymaklı Municipality within the District of Nevşehir, Odunpazarı Municipality within the District of Eskişehir, all of which are located in the Central Anatolian Region, and Seyrek Municipality within the District of İzmir located in the Aegean Region. ${ }^{[3]}$ These localities represent different geographical, social, economic, political and cultural contexts in Turkey.

Table 1

Case Localities of the Present Study ${ }^{[4]}$

\begin{tabular}{|c|c|c|c|c|}
\hline & $\begin{array}{l}\text { Gazi } \\
\text { (Samsun) }\end{array}$ & $\begin{array}{l}\text { Kaymaklı } \\
\text { (Nevşehir) }\end{array}$ & $\begin{array}{l}\text { Odunpazarı } \\
\text { (Eskişehir) }\end{array}$ & $\begin{array}{l}\text { Seyrek } \\
\text { (İzmir) }\end{array}$ \\
\hline \multirow{2}{*}{$\begin{array}{l}\text { Geographical locations } \\
\text { of the case localities }\end{array}$} & North Anatolia & Central Anatolia & Central Anatolia & $\begin{array}{l}\text { West Anatolia } \\
\text { (Aegean region) }\end{array}$ \\
\hline & & & & \\
\hline $\begin{array}{l}\text { Populations of the } \\
\text { localities (2000) }\end{array}$ & 139,962 & 5,811 & 274,038 & 3,865 \\
\hline $\begin{array}{l}\text { Legal status in the } \\
2004-2009 \text { period }\end{array}$ & $\begin{array}{l}\text { Metropolitan } \\
\text { sub-provincial } \\
\text { municipality }\end{array}$ & Town settlement & $\begin{array}{l}\text { Metropolitan } \\
\text { sub-provincial } \\
\text { municipality }\end{array}$ & Town settlement \\
\hline Project & \multicolumn{4}{|c|}{ Local Government-NGO Cooperation in Participatory Democracy } \\
\hline Year started & \multicolumn{4}{|l|}{2005} \\
\hline Funded by & \multicolumn{4}{|l|}{ European Union } \\
\hline $\begin{array}{l}\text { Project initiator/ } \\
\text { coordinator }\end{array}$ & \multicolumn{4}{|c|}{ Civil Society Development Center (STGM) } \\
\hline Major stakeholders & \multicolumn{4}{|c|}{ STGM and municipalities, and NGOs active in their localities } \\
\hline $\begin{array}{l}\text { Role of STGM } \\
\text { in the process }\end{array}$ & \multicolumn{4}{|c|}{$\begin{array}{l}\text { Extending technical support to civil organizations concerning participatory } \\
\text { methods and building civil networks }\end{array}$} \\
\hline
\end{tabular}

[3] Two municipalities, Gazi (Samsun) and Seyrek (İzmir), where the participatory processes were conducted, ceased to exist in March 2009 following the enactment of Metropolitan Municipality Law (No: 5747, ratified on 22.03.2008). As a result, Gazi Municipality merged with İlkadım Municipality (Samsun) with all its neighborhoods, and Seyrek Municipality became a neighborhood of the Menemen (İzmir) District.

[4] Maps showing the geographical locations of the localities are taken from the portals of the local municipalities (accessed April 5, 2012, url: http://www.yerelnet.org.tr/belediyeler/belediye.php?belediyeid=128711). 
Among the case localities, while the Gazi and Odunpazarı Municipalities are metropolitan sub-provincial municipalities with respective populations of 139,962 and 274,038, Kaymaklı and Seyrek are town settlement municipalities, with respective populations of 5,811 and 3,865. In this part of the study the partner case localities are presented by comparing their socio-economic development levels which will illustrate some key differences between the localities (Table 2).

Table 2

The Development Level Indicators and the Case Areas of the Present Study

\begin{tabular}{|c|c|c|c|c|}
\hline & $\begin{array}{l}\text { Odunpazarı } \\
\text { (Eskişehir } \\
\text { Center) }\end{array}$ & $\begin{array}{l}\text { Gazi } \\
\text { (Samsun } \\
\text { Center) }\end{array}$ & $\begin{array}{l}\text { Kaymaklı } \\
\text { (Nevşehir } \\
\text { Center) }\end{array}$ & $\begin{array}{l}\text { Seyrek } \\
\text { (Menemen/ } \\
\text { İzmir) }\end{array}$ \\
\hline INDICATORS & \multicolumn{4}{|c|}{ Number and ratio (the order among the 872 districts) } \\
\hline Urbanization ratio $(\%)$ & $92.92(8)$ & $83.07(30)$ & $64.58(136)$ & $40.26(466)$ \\
\hline $\begin{array}{l}\text { The increasing rate of } \\
\text { population }(\%)\end{array}$ & $14.91(257)$ & $16.88(232)$ & $19.10(202)$ & $40.88(47)$ \\
\hline Density of population & $195(80)$ & $591(10)$ & $196(77)$ & $165(110)$ \\
\hline $\begin{array}{l}\text { Ratio of household } \\
\text { dependency }\end{array}$ & $41.49(840)$ & $47(765)$ & $54.05(562)$ & $55.71(498)$ \\
\hline Average household size & $3.49(819)$ & $4.06(666)$ & $4.18(637)$ & $4.09(659)$ \\
\hline $\begin{array}{l}\text { Ratio of the employees in } \\
\text { agriculture sector (\%) }\end{array}$ & $12.64(869)$ & $25.31(850)$ & $50.20(733)$ & $57.86(685)$ \\
\hline $\begin{array}{l}\text { Ratio of the employees in } \\
\text { the industrial sector }(\%)\end{array}$ & $26.21(23)$ & $12.55(102)$ & $7.84(220)$ & $13.73(89)$ \\
\hline $\begin{array}{l}\text { Ratio of the employees in } \\
\text { the service sector }(\%)\end{array}$ & $61.15(24)$ & $62.15(21)$ & $41.96(102)$ & $28.41(238)$ \\
\hline $\begin{array}{l}\text { Ratio of unemployment } \\
(\%)\end{array}$ & $10.58(119)$ & $12.44(76)$ & $6.31(326)$ & $4.76(478)$ \\
\hline Ratio of the literate (\%) & $94.24(17)$ & $91.42(101)$ & $90.08(155)$ & $87.34(311)$ \\
\hline Ratio of infant deaths (\%) & $37.19(483)$ & $39.99(416)$ & $34.15(578)$ & $47.80(230)$ \\
\hline $\begin{array}{l}\text { General budget income } \\
\text { per person (TL) }\end{array}$ & $306.747(33)$ & $272.101(38)$ & $136.439(102)$ & $17.292(645)$ \\
\hline Ratio of tax incomes (\%) & $0.73746(7)$ & $0.33110(18)$ & $0.05488(113)$ & $0.05169(119)$ \\
\hline $\begin{array}{l}\text { Ratio of the agricultural } \\
\text { production in Turkey (\%) }\end{array}$ & $0.24495(108)$ & $0.12537(245)$ & $0.37860(52)$ & $0.31078(76)$ \\
\hline
\end{tabular}

The comparison of development levels of the case localities drew data from the report of the State Planning Organization (SPO) that was prepared based on the administrative structure of Turkey in 2000. The date of the report is important as two of the case localities in the present study, Gazi and Seyrek, ceased to exist in 2009. The report published in 2004 reflects the socio-economic situations of the case localities when STGM conducted the case project.

According to the report of SPO (2004) the most developed locality among the cases is Odunpazarı, a central-metropolitan district of Eskişehir. Odunpazarı was ranked 
$7^{\text {th }}$ in terms of development of 872 districts across Turkey. The second most developed case district, Gazi, is a central-metropolitan district of Samsun which was ranked $25^{\text {th }}$ in order of development. The third most developed district was the Kaymakl1 sub-district municipality, a central district of Nevşehir. According to the report (2004), the central district of Nevşehir was ranked 89 by the SPO. Finally, the least developed project participant was Seyrek, a sub-district municipality of Menemen, ranked 142 out of the 872 districts. A comparison of the four case localities reveals broad differences among them in terms of the development level indicators (Table 2).

\section{Methodology of the Research: The Exploration of Success Attributes}

The intention of this study is to explore the perceived attributes of success and the differences between the definitions of success of the participant groups. For this reason, the present research is designed as an exploratory multiple-case study that allows for the exploration and comparison definition of success of contextually different participant groups within the basis of the common project in the case of the Local Government and NGO Cooperation in the Participatory Democracy project in four contextually different settings in Turkey, Gazi, Kaymaklı, Odunpazarı and Seyrek.

The data collection process of this exploratory case study was conducted in the four localities between August 2011 and October 2011, during which 45 in-depth interviews were conducted with the participants in the four participant localities. The 45 interviews were spread among the four locations as follows: 7 from Gazi, 14 from Kaymakl1, 13 from Seyrek and 11 from Odunpazarı (appendix 1: the background information of respondents). In each locality, the number of interviews conducted depended on the number of participants who had attended at least one of the main meetings organized by STGM during the project.

STGM as an organizer actor held three main meetings in which all of the participant localities participated, and invited seven participants from each locality to these plenary activities. Kaymakl1, Odunpazarı and Seyrek groups participated in all of these gatherings with different social actors. As a result, a total of respectively fourteen, thirteen and eleven social actors took part in the meetings from these localities. On the other hand, Gazi participated in two of these three meetings with a total of seven actors. Therefore, the total participant numbers of people attending the main meetings from each case locality were different. ${ }^{[5]}$

All interviews were conducted in Turkish, it being the mother tongue of all respondents. During the interviews open-ended questions were asked of the participants, and in-depth interviews were reported and recorded after gaining the permission of the participants. In line with the focus of the study, the part of the interview that included an open-ended question related to success, the first question in the interview, was analyzed and presented.

[5] The results are presented in each case as an average per person. 
The open-ended question was: "How do you define the success for the participatory practice?"

In the present study, the respondents' own descriptions of success are accepted as the basis of the content analysis used to analyze the collected qualitative data. During the content analysis process, "words" were considered to be the most suitable unit of analysis from among the other options that included "sentence" and "paragraph." Since the aim of the study was to reveal differences between the definitions of success of different participant groups, and since all different participant groups could use the same concepts, the aim of the study could be realized only through a comparison of the frequency of the concepts mentioned. As the smallest possible unit for a content analysis, words were selected in line with Berg (2001), who suggests that words are the most suitable unit when researchers are relying on the frequency distribution of words or terms. A further advantage in the use of words in this regard was that the degree of interpretation required by the researcher from the subjective descriptions of the interviewees was minimized. This was important not only for this study, but for all studies featuring quantitative analyses, since they are generally criticized for being subjective and relative, and that the findings of each qualitative analysis are dependent upon the researcher conducting the study.

In this way, the perceived attributes of success were explored from the subjective descriptions of the respondents; and this systematic analysis technique allowed the answers to be assigned into content categories from which it was possible to quantify how often specific issues were emphasized in the course of the interviews. The analysis process followed four main steps. First, tables of information were created to allow the relationship among the different categories of information to be displayed, and to display the categories of success definition. The first step in this process revealed the content groups and the categories of attributes of success. Second, all of issues raised by the respondents were listed to reduce the information to themes or categories. Third, similar issues were grouped together and categorized under different labels, the development of which took into consideration participatory practices in the literature, especially the literature related to success. Through content analysis, the content groups and attributes of success, as mentioned by respondents, were determined.

\section{Findings of the Study: How do Respondents Define Success for the Participatory Practice?}

This part of the study presents the definitions of success based on the respondents' subjective descriptions as formulated by the participants of the case participatory project. First, the perceived success attributes and content groups for the Local Government and NGO Cooperation in the Participatory Democracy project will be presented, and then the perceived success content groups in each case locality will be presented through a comparison of the findings. 


\section{Success Definition of the Participants in the Local Government and NGO Cooperation in the Participatory Democracy Project}

The content analysis revealed 23 attributes of success which were then categorized into five content groups as "process," "end products," "personal," "interpersonal," and "cultural-contextual." Table 3 presents the attributes and the content groups for the total sample.

The most commonly mentioned factors were those falling under the process content group (43.3\%), comprising the attributes of "process characteristics, "activities / education / organizations in the process," "leadership in the process," "sustainability" and "management in the process." The following quotes are examples of the attributes cited in the process content group:

"The most important thing for me is sustainability in terms of the success of participatory practice" (a respondent from Seyrek, in-depth interview, August 23, 2011).

"Success means contributing to individuals' lives and providing learning during the participatory process" (a respondent from Seyrek, in-depth interview, August 24, 2011).

"Continuity and institutionalization are needed for success. But first and foremost, the process must not be in the hands of one person, as participatory processes should be like social movements" (a respondent from Kaymakl1, in-depth interview, October 14, 2011)

The second most mentioned factors were those falling under the end products content group (23.3\%, comprising attributes of "products of the practice," "social learning," and "reaching the objectives of the process." The following quote is an example of the attributes cited in the "end products" content group:

"Successful participatory practices mean successful end products" (a respondent from Odunpazarı, in-depth interview, August 4, 2011).

The third most mentioned factors were those falling under the personal content group (15.2 percent) comprising the attributes of "active citizenship" and "personal characteristics." The following quotes are examples of the attributes cited in the "personal" content group:

"Success is the willing participation of individuals" (a respondent from Odunpazarı, in-depth interview, August 8, 2011).

"Continuing the participatory process with the same desires and willingness as at the beginning of the process" (a respondent from Gazi, in-depth interview, October 25, 2011).

"Success depends on the individual being able to accept the differences between himself/herself and the other participants" (a respondent from Gazi, in-depth interview, October 25, 2011). 
Table 3

Attributes and Content Groups of Success in the Local Government \& NGO Cooperation in the Participatory Democracy Project.

\begin{tabular}{|c|c|c|c|c|c|}
\hline \multicolumn{6}{|c|}{ RESPONDENTS' DEFINITIONS OF SUCCESS } \\
\hline Content Groups & $\begin{array}{l}\text { Perceived Success } \\
\text { Attributes }\end{array}$ & $\begin{array}{l}\text { Frequency } \\
\text { of Mention }\end{array}$ & $\%$ & $\begin{array}{l}\text { Frequency } \\
\text { of Mention }\end{array}$ & $\%$ \\
\hline \multirow{5}{*}{ Process } & Process characteristics & 52 & 15.9 & \multirow{5}{*}{142} & \multirow{5}{*}{43.3} \\
\hline & $\begin{array}{l}\text { Activities/education/ } \\
\text { organizations in the process }\end{array}$ & 30 & 9.2 & & \\
\hline & Leadership in the process & 24 & 7.3 & & \\
\hline & Sustainability & 23 & 7.0 & & \\
\hline & Management in the process & 13 & 4 & & \\
\hline \multirow{3}{*}{ End Products } & Products of the practice & 45 & 13.7 & \multirow{3}{*}{73} & \multirow{3}{*}{22.} \\
\hline & Social learning & 14 & 4.3 & & \\
\hline & Reaching the objectives of the process & 14 & 4.3 & & \\
\hline \multirow{2}{*}{ Personal } & Active citizenship & 37 & 11.3 & \multirow{2}{*}{$\mathbf{5 0}$} & \multirow{2}{*}{15.2} \\
\hline & Personal characteristics & 13 & 4 & & \\
\hline \multirow{4}{*}{ Interpersonal } & Interpersonal relationships & 18 & 5.5 & \multirow{4}{*}{32} & \multirow{4}{*}{9.8} \\
\hline & Hidden agenda & 8 & 2.4 & & \\
\hline & Persuasion & 3 & 0.9 & & \\
\hline & Power & 3 & 0.9 & & \\
\hline \multirow{4}{*}{$\begin{array}{l}\text { Cultural } \\
\text { Contextual }\end{array}$} & NGOs & 17 & 5.2 & \multirow{4}{*}{31} & \multirow{4}{*}{9.4} \\
\hline & Contextual & 6 & 1.8 & & \\
\hline & Central persons & 5 & 1.5 & & \\
\hline & Culture & 3 & 0.9 & & \\
\hline TOTAL & & 328 & 100 & 328 & 100 \\
\hline
\end{tabular}

The least mentioned factors were those falling under the interpersonal content group (9.8 percent) and the "cultural-contextual" content group (9.4\%) which were almost equally cited. While the "interpersonal" content group comprises "interpersonal relationships," "hidden agenda," "persuasion" and "power" attributes, the "culturalcontextual" content group is composed of the "NGOs," "context," "central persons" and "culture" attributes. Of the following quotes, the first is an example of the cited attributes of the "interpersonal" content group, and the second is an example from the "cultural-contextual" content group:

"What is success? It is building consensus by persuading and trusting each other" (a respondent from Kaymakl1, in-depth interview, October 13, 2011).

"The success of participatory practices depends on the NGOs and their capabilities. In the North Anatolia region there is a need to take some lessons from previous successful participatory practices, and to present the successful participatory experiences and NGO histories to the public in serious organizations" (a respondent from Gazi, in-depth interview, October 25, 2011). 
The findings reveal that in terms of the conceptualization of participation, the participants in the case project conceptualized participation more as an end in itself than as a means to an end. Moreover, in contrast to the literature in which discussions of success focus mainly on process and end products, the respondents mentioned also personal, interpersonal and cultural-contextual attributes which accounted for almost one-third of the total. However, it should be noted that the definitions of success of the different participant groups differed when evaluated separately.

\section{Success Definitions of Participant Groups from Gazi, Kaymakl,, Odunpazarı and Seyrek}

The perceived content groups of the four case localities are presented in Table 4, which reveals the differences in definitions of success in contextually different settings.

Table 4

Content Groups of Definitions of Success in Gazi, Kaymaklı, Odunpazarı and Seyrek

\section{SUCCESS DEFINITION OF RESPONDENTS}

\section{LOCALITIES}

\begin{tabular}{lllllllll} 
& \multicolumn{2}{c}{ GAZI } & \multicolumn{2}{c}{ KAYMAKLI } & \multicolumn{2}{c}{ ODUNPAZARI } & \multicolumn{2}{c}{ SEYREK } \\
\cline { 2 - 9 } Content Groups & $\begin{array}{l}\text { Frequency } \\
\text { of mention } \\
\text { per person }\end{array}$ & $\begin{array}{l}\text { Frequency } \\
\text { of mention } \\
\text { per person }\end{array}$ & $\begin{array}{l}\text { \% } \\
\text { Process }\end{array}$ & $\begin{array}{l}\text { Frequency } \\
\text { of mention } \\
\text { per person }\end{array}$ & $\begin{array}{l}\text { Frequency } \\
\text { of mention } \\
\text { per person }\end{array}$ & $\%$ \\
\hline $\begin{array}{l}\text { Products } \\
\text { Personal }\end{array}$ & 0.71 & 47 & 3.14 & 45.5 & 3.81 & 37.5 & 0.69 & 44.8 \\
\hline $\begin{array}{l}\text { Interpersonal } \\
\begin{array}{l}\text { Cultural- } \\
\text { contextual }\end{array}\end{array}$ & 2.14 & 3 & 2.29 & 33.2 & 2.64 & 26 & 0.69 & 44.8 \\
\hline $\begin{array}{l}\text { Frequency of } \\
\text { mention per } \\
\text { person }\end{array}$ & 15 & 0.64 & 9.3 & 2.36 & 23.2 & 0 & 0 \\
\hline TOTAL & 14.29 & 16.1 & 0.4 & 5.8 & 0.9 & 8.9 & 0.08 & 5.2 \\
\hline & 100 & 10.9 & 0.43 & 6.2 & 0.45 & 4.4 & 0.08 & 5.2 \\
\hline
\end{tabular}

According to the results of the content analysis for each participant group, while defining the success of the participatory practice, the respondents from Gazi mostly mentioned attributes in the process (47\%) and cultural-contextual (18.9\%) content groups; the respondents from Kaymakl1 mostly mentioned attributes in process (45.5\%) and end products (33.2\%) content groups; the respondents from Odunpazarı mostly mentioned attributes in the process (37.5\%), end products (26\%) and personal (23.2\%) content groups; and respondents from Seyrek mostly and equally mentioned attributes in the process $(44.8 \%)$ and end products (44.8 \%) content groups. All four localities defined the success of a participatory practice based mostly on the process attributes, 
followed by end products attributes, with the exception of the participants from Gazi, who mentioned end products least, instead attributing secondary importance to culturalcontextual attributes.

In terms of the conceptualization of participatory practices, the findings reveal that while the participant group from Gazi accepts participation as an end in itself, mentioning the process content group (47\%) more than the end products content group (3\%), the participant group of Seyrek accepts participation both as an end in itself and as means to an end, mentioning the process and end products an equal number of times $(44.8 \% / 44.8 \%)$. On the other hand, the participants from Kaymaklı mentioned both the process $(45.5 \%)$ and end products $(33.2 \%)$ content groups, similar to the participants from Odunpazar1, who also mentioned both the process (37.5\%) and end products $(26 \%)$ content groups. The fact that the participants from Kaymaklı and Odunpazarı mentioned the process content group more than end products content group, but that the ratios of frequency of mention per person of these content groups is the same leads to the understanding that both groups of participants conceptualize participation both as a means to an end and as an end in itself, as with the Seyrek group.

\section{Graph 1}

\section{The Four Participant Groups and Distribution of the Mentioned Content Groups}

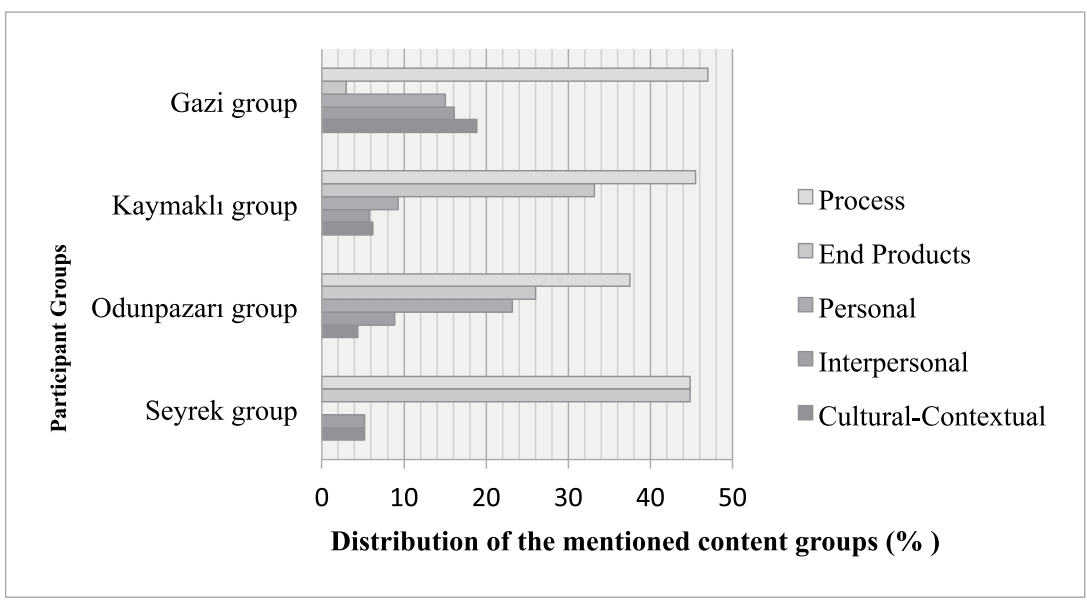

In addition to the process and end products content groups, all of the participant groups mentioned personal, interpersonal and cultural-contextual content groups at different levels (Table 4, Graph 1). The combined personal, interpersonal and cultural-contextual content groups accounted for over half the mentions in the Gazi group, and one-third of the mentions of the Odunpazarı group, one-fifth of the mentions of the Kaymakl1 group, and one-tenth of the mentions of the Seyrek group. The Gazi group mentioned the personal, interpersonal and cultural-contextual content groups almost equally, (15, 16.1 and $18.9 \%$ respectively), as was the case with the Kaymakl group (9.3, 5.8 and $6.2 \%$ respectively). In contrast, in Odunpazarı the personal content group accounted for 
$23.2 \%$ of total mentions, while the interpersonal and cultural-contextual content groups accounted for 8.9 and $4.4 \%$ of mentions respectively. Finally, in the Seyrek group, the interpersonal and cultural-contextual content groups were mentioned equally, at $5.2 \%$, but no mention was made of the personal content group. A closer evaluation of the content groups in the definition of success for each participant group reveals clear differences in their perceptions (Table 5).

Table 5

The Findings of this Study

\begin{tabular}{lllll}
\hline & Gazi & Kaymaklı & Odunpazarı & Seyrek \\
\hline $\begin{array}{l}\text { Socio-economic } \\
\text { development levels }\end{array}$ & $25^{\text {th }}$ & $89^{\text {th }}$ & $7^{\text {th }}$ & $142^{\text {nd }}$ \\
\hline $\begin{array}{l}\text { Conceptualization of } \\
\text { participation }\end{array}$ & $\begin{array}{l}\text { As an end in } \\
\text { itself }\end{array}$ & As an end in itself \& As a mean to an end & Process \& \\
\hline $\begin{array}{l}\text { Most mentioned content } \\
\text { group }\end{array}$ & Process & Process & Process & Products \\
\hline $\begin{array}{l}\text { Second most mentioned } \\
\text { content group }\end{array}$ & $\begin{array}{l}\text { Cultural- } \\
\text { contextual }\end{array}$ & Products & Products & Cultural - \\
\hline $\begin{array}{l}\text { Third most mentioned } \\
\text { content group }\end{array}$ & Interpersonal & Personal & Personal & Interpersonal \\
\hline $\begin{array}{l}\text { Fourth most mentioned } \\
\text { content group }\end{array}$ & Personal & $\begin{array}{l}\text { Cultural- } \\
\text { contextual }\end{array}$ & Interpersonal & \\
\hline $\begin{array}{l}\text { Fifth most mentioned } \\
\text { content group }\end{array}$ & Products & Interpersonal & $\begin{array}{l}\text { Cultural- } \\
\text { contextual }\end{array}$ & --- \\
\hline
\end{tabular}

\section{Conclusion: What is Revealed by the Definitions of Success of Different Participant Groups?}

This study has argued that the evaluation criteria in a participatory practice should be developed by all participants through a shared understanding of success based on unique criteria. Accordingly, the present study focuses on the definitions of success of the participants in the case of the Local Government and NGO Cooperation in the Participatory Democracy project, by aiming, first, to explore the perceived attributes and content groups of success obtained from the subjective descriptions of respondents; second, to reveal the differences between the definitions of success of contextually different participant groups; and third, to show the differences between the participation conceptualizations of the participant groups, depending on their own definitions of success. In addition to its objectives, the study reveals a relation between the socioeconomical development levels of localities and the success definitions of participant groups from these localities.

In parallel to theoretical discussions in the literature, the findings of the content analysis of the definition of success in participatory practices has revealed that the respondents define the success of participatory practices based mainly on the process 
and end products attributes, accounting for almost two-thirds of all mentions in the interviews. However, in addition to process and end products attributes, when defining the success of a participatory practice the respondents also referred to personal, interpersonal and cultural-contextual content groups almost one-third of the time, which is a result that is rare in previous participation literature.

This empirical finding supports the definition of participatory practice as a process that is activated by individuals and their interaction within a unique social context. In such an active process, personal attributes, which are psychological factors, and interpersonal and cultural-contextual attributes, which are socio-psychological factors would also be influential in the success of the process. Accordingly, in addition to the 23 attributes of success (which were categorized into five content groups as process, end products, personal, interpersonal and cultural-contextual), this study has also revealed the existence of a strong relationship between the perception of success and the psychological and socio-psychological dimensions of participatory practices.

In exploring how the respondent groups define the success of a participatory practice, the study has revealed that contextually different participant groups define success in different ways. In the conceptualization of participation, the study revealed that while the Gazi group perceived it as an end in itself, the Kaymaklı, Odunpazarı and Seyrek groups saw it both as an end in itself, and as a means to an end.

In exploring how the respondent groups defined the success of a participatory practice, the study revealed that contextually different participant groups defined both the success and the conceptualized participatory practice in different ways. In the conceptualization of participation, the study revealed that while the Gazi group perceived it as an end in itself, the Kaymakl1, Odunpazarı and Seyrek groups saw it both as an end in itself, and as a means to an end.

This study has explored that how the respondents define the success of a participatory experience is not only based on process and its products, but also on the personal, interpersonal and cultural-contextual attributes, these being the psychological, sociopsychological and socio-cultural dynamics of participatory practices. All participant groups mentioned the personal, interpersonal and cultural-contextual content groups, but at different levels, aside from the Seyrek group. These content groups were mentioned by the participants from Gazi, Odunpazarı, Kaymaklı and Seyrek from most to least. While the personal content group was most often mentioned by the Odunpazar1 group as the most developed case area, it was not mentioned at all by the Seyrek group as the least developed case area. Evaluating these findings by comparing Odunpazarı and Seyrek, which are at opposite ends of the socio-economic scale of the case study areas, this result reveals that in less developed cases, the success of participatory practices is determined mainly according to socio-psychological attributes, while in more developed cases the success of participatory practices is determined mostly according to psychological attributes. Moreover, a parallelism has been revealed between the development levels of the case areas and their frequency of mentioning attributes in the personal content group. It could be inferred that this finding is related to the more personal attitudes observed in the more developed and urbanized locations, and the greater collectivism noted in 
the less developed and smaller contexts. On the other hand, the participants from both Gazi and Kaymakl1, as the second and third most socio-economically developed areas in the study, mentioned attributes in the personal, interpersonal and cultural-contextual content groups almost at the same levels in their own context. This finding supports the parallelism noted between the socio-economic development levels of contextually different participant groups and their preference for psychological, socio-psychological and cultural-contextual attributes when defining the success of participatory practices. In other words, it shows the changing effects of the psychological, socio-psychological and cultural-contextual dimensions on participatory practices, indicating that their success depends on the socio-economic development level of the case localities in which participatory practices are conducted.

An analysis of the definitions of success of the different participant groups reveals that all of the empirical findings support the argument of this study: that each participatory practice is unique, and should be evaluated in its own context by its participants rather than according to pre-defined criteria of success. The four contextually different participant groups in this study engaged in participatory practices as part of the same project, and all with the same objectives; however the participant groups defined success in different ways, mentioning five perceived content groups at different levels. Moreover, this study has shown that in addition to criteria related to process and end products, there is a need also to consider personal, interpersonal and cultural-contextual criteria when evaluating the success of participatory practices. These support the context dependency of participatory practices and the need to evaluate each participatory practice in its own context, rather than according to the same criteria of success.

The findings of this exploratory research reveal that participatory practices should take into account the unique definitions of success or the criteria of success of each participant group. Moreover, future participatory practices and researches into participatory practices should be conducted considering the psychological and socio-psychological effects on the practices and their success, bearing in mind that these attributes change according to contextual differences. Further research studies could focus on the different definitions of success within the context of other participatory practices; and on an examination of the relationship between definitions of success and the participants' demography and background, with reference to factors such as age, gender, education, political persuasion, religion, social level and socio-economic conditions; their contextual differences; and their expectations from the participatory practice. Such studies could explore the effects of the participants' demography and background on their conceptualization of participation in relation to their definition of success in participatory practices. Moreover, the effects of the discussed content groups, being process, end products, personal, interpersonal and cultural-contextual, on participatory practices and their success should be explored and examined in terms of their beneficial and detrimental effects on contextually different participatory practices. Such researches could help in the development of ways to improve the success of participatory practices. Through these researches, a path may be opened to more successful participatory practices based on a shared understanding of success among the participants within a unique context. 


\section{References}

Arnstein, S.R. (1969). “A Ladder of Citizen Participation,” Journal of the American Institute of Planners, 35(4): 216-224.

Berg, B.L. (2001), “An Introduction to Content Analysis," in B.L. Berg (ed.), Qualitative Research Methods for the Social Sciences: 238-267. Boston: Allyn and Bacon.

Brand, R. and Gaffikin, F. (2007). "Collaborative Planning in an Uncollaborative World," Planning Theory, 6(3): 282-313, doi: 10.1177/1473095207082036.

Buchy, M. and Hoverman, S. (2000). "Understanding Public Participation in Forest Planning: A Review," Forest Policy and Economics, 1: 15-25.

Carnes, S.A., Schweitzer, M., Peelle, E.B., Wolfe, A.K., and Munro, J.F. (1998). "Measuring the Success of Public Participation on Environmental Restoration and Waste Management Activities in the U.S. Department of Energy," Technology in Society, 20: 385-406.

Chess, C. and Purcell, K. (1999). "Public Participation and the Environment: Do We Know What Works?" Environmental Science and Technology, 33(16): 2685-2692.

Civil Society Development Center. (2005). Katılımcı Demokraside Yerel Yönetim - STK İşbirliği 1. Toplantı Raporu.

Civil Society Development Center, Accessed: 30 March, 2012; http://www.stgm.org.tr.

Coglianese, C. (2002). Is Satisfaction Success? Evaluating Public Participation in Regulatory Policymaking. John F. Kennedy School of Government, Harvard University Faculty Research Working Papers Series, 1-26.

Cooke, B. and Kothari, U. (2001). "The Case for Participation as Tyranny," in B. Cooke and U. Kothari (eds.), Participation: a New Tyranny?: 1-15. London, New York: Zed Books.

Cooper, J. (2002). Evaluating Public Participation in the Environmental Assessment of Trade Negotiations. Cooper and Associates Research.

Crosby, N., Kelly, Janet M., and Schaefer P. (1986). "Citizens Panels: A New Approach to Citizen Participation," Public Administration Review, 46(2): 170-178.

Dalton, T.M. (2006). "Exploring Participants' Views of Participatory Coastal and Marine Resource Management Processes," Coastal Management, 34: 351-367, doi: 10.1080/08920750600860209.

Dowling, B., Powell, M. and Glendinning C. (2004). "Conceptualising Successful Partnerships," Health and Social Care in the Community, 12(4): 309-317.

Fung, A. and Wright, E.O. (2001). "Thinking about Empowered Participatory Governance," Politics and Society, 29(1): 5-41.

Innes, J.E. and Booher, D.E. (1999). “Consensus Building and Complex Adaptive Systems,” Journal of the American Planning Association, 65(4): 412-423,

doi: 10.1080/01944369908976071.

Koontz, T.M. and Craig W. (2006). "What Do We Know and Need to Know about the Environmental Products of Collaborative Management?” Public Administration Review, Special Issue: 111-121.

Kulözü, N. (2011). “Planlamaya Katılım: Araç mı, Amaç mı?” KBAM Kentsel ve Bölgesel Araştırmalar 2. Sempozyumu, Planlamanın Dünü, Bugünü, Yarını: Planlamada Yeni Söylem Arayışları, 159-170.

Kulözü, N. and Tekeli, İ. (2014). "Socio-Psychological Factors Affecting Participatory Planning Processes At Interactional Level," Megaron, 9(1): 1-13. 
Local Municipalities Portal; Accessed: June 2012; http://www.yerelnet.org.tr/belediyeler/belediye. php?belediyeid $=128711$.

Mascarenhas, M. and Scarce, R. (2004). "The Intention Was Good: Legitimacy, Consensus-Based Decision Making, and the Case of Forest Planning in British Columbia, Canada," Society and Natural Resources, 17(1): 17 -38, doi: 10.1080/08941920490247227.

McCool, Stephen F. and Guthrie, K. (2001). "Mapping the Dimensions of Successful Public Participation in Messy Natural Resources Management Situations," Society and Natural Resources, 14(4): 309-323, doi: $10.1080 / 713847694$.

Mostert, E., Pahl-Wostl, C., Rees, Y., Searle, B., Tàbara, D., and Tippett, J. (2007). "Social Learning in European River-Basin Management: Barriers and Fostering Mechanisms from 10 River Basins," Ecology and Society, 12(1): 19, url: http://www.ecologyandsociety.org/vol12/iss1/art19/.

Pretty, J. (1995). Regenerating Agriculture. Policies and Practice for Sustainability and Self Reliance. London: Earthscan Publications Ltd.

Rosener, J.B. (1978). "Citizen Participation: Can We Measure Its Effectiveness?” Public Administration Review, 38 5): 457-463, url: http://www.jstor.org/stable/975505.

Rowe, G. and Frewer, Lynn J. (2000). "Public Participation Methods: A Framework for Evaluation," Science, Technology, and Human Values, 25(1): 3-29, doi: 10.1177/016224390002500101.

Rowe, G., Marsh, R. and Frewer, Lynn J. (2004). "Evaluation of a Deliberative Conference," Science, Technology, and Human Values, 29(1) 88-121, doi: 10.1177/0162243903259194.

Shindler, B. and Neburka, J. (1997). "Public Participation in Forest Planning: Attributes of Success," Journal of Forestry, 95(1): 17-19.

State Planning Organization (SPO) (2004). Ilçcelerin Sosyo-Ekonomik Gelişmişlik Siralaması Araştırması. Bölgesel Gelişme Ve Yapısal Uyum Genel Müdürlüğü, url: http://ekutup.dpt.gov.tr/.

Tekeli, İ. (1990). “Kent Planlamas1 ve Kat1lım Üzerine Düşünceler,” Planlama Dergisi, 90 (3-4): 8-13.

Tuler, S. and Webler, T. (1999). "Voices from the Forest: What Participants Expect of a Public Participation Process," Society \& Natural Resources, 12(5): 437-453, doi: 10.1080/089419299279524.

Tuler, S., Webler, T., Shockey, I. and Stern, Paul C. (2002). "Factors Influencing the Participation of Local Governmental Officials in the National Estuary Program," Coastal Management, 30(1): 101120, doi: 10.1080/08920750252692643.

Webler, T. and Tuler, S. (2000). "Fairness and Competence in Citizen Participation: Theoretical Reflections from a Case Study," Administration and Society, 32: 566-595, doi: 10.1177/00953990022019588.

---- (2001). "Public Participation in Watershed Management Planning," Human Ecology Review, $8(2), 29-39$.

---- (2002). "Unlocking Puzzle of Public Participation," Science, Technology and Society, 22(3): 179-189, doi: 10.1177/02767602022003002.

---- (2006). "Four Perspectives on Public Participation Process in Environmental Assessment and Decision Making: Combined Results from 10 Case Studies," Policy Studies Journal, 34(4): 699-722, doi: 10.1111/j.1541-0072.2006.00198.x.

Webler, T., Tuler, S., Shockey, I., Stern, P.C. and Beattle, R. (2003). "Participation by Local Governmental Officials in Watershed Management Planning," Society and Natural Resources, 16: 105-121, doi: 10.1080/08941920390174238. 
White, S.C. (1996). "Depoliticising Development: The Uses and Abuses of Participation," Development in Practice, 6(1): 6-15, doi: 10.1080/0961452961000157564.

Wondolleck, J. and Yaffee, S. (2000). Making Collaboration Work: Lessons from Innovation in Natural Resource Management. Covelo CA: Island Press.

Appendix 1.

Background Information of Respondents.

\begin{tabular}{|c|c|c|c|c|c|c|c|}
\hline \multirow{2}{*}{\multicolumn{3}{|c|}{ Background/Localities }} & \multicolumn{4}{|c|}{ Sample in } & \multirow{3}{*}{$\begin{array}{l}\text { TOTAL } \\
45\end{array}$} \\
\hline & & & \multirow{2}{*}{$\begin{array}{c}\text { Gazi } \\
7\end{array}$} & \multirow{2}{*}{$\begin{array}{l}\text { Kaymaklı } \\
14\end{array}$} & \multirow{2}{*}{$\begin{array}{l}\text { Odunpazarı } \\
11\end{array}$} & \multirow{2}{*}{$\frac{\text { Seyrek }}{13}$} & \\
\hline & Respondents' & count & & & & & \\
\hline & Number & $\%$ within local & $16 \%$ & $31 \%$ & $24 \%$ & $29 \%$ & $100 \%$ \\
\hline \multirow{4}{*}{ 舀 } & \multirow{2}{*}{ Female } & count & 2 & 9 & 7 & 7 & 25 \\
\hline & & $\%$ within local & $29 \%$ & $64.3 \%$ & $63.6 \%$ & $53.8 \%$ & $55 \%$ \\
\hline & \multirow{2}{*}{ Male } & count & 5 & 5 & 4 & 6 & 20 \\
\hline & & $\%$ within local & $71 \%$ & $35.7 \%$ & $36.4 \%$ & $46.2 \%$ & $45 \%$ \\
\hline \multirow{6}{*}{ 离 } & \multirow{2}{*}{ Primary school } & count & - & 2 & - & 11 & 15 \\
\hline & & $\%$ within local & - & $14.3 \%$ & - & $84.6 \%$ & $33 \%$ \\
\hline & \multirow{2}{*}{ High school } & count & 1 & 6 & 2 & - & 7 \\
\hline & & $\%$ within local & $14.3 \%$ & $42.9 \%$ & $18.2 \%$ & - & $16 \%$ \\
\hline & \multirow{2}{*}{ University } & count & 6 & 6 & 9 & 2 & 23 \\
\hline & & $\%$ within local & $85.7 \%$ & $42.9 \%$ & $81.8 \%$ & $15.4 \%$ & $51 \%$ \\
\hline \multirow{6}{*}{ 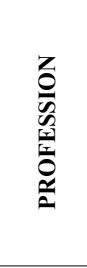 } & \multirow{2}{*}{$\begin{array}{l}\text { Mayor and advisor of } \\
\text { mayor }\end{array}$} & count & 4 & 2 & 2 & 1 & 9 \\
\hline & & $\%$ within local & $57.1 \%$ & $14.3 \%$ & $18.2 \%$ & $7.7 \%$ & $20 \%$ \\
\hline & \multirow{2}{*}{ NGO's agency } & count & 3 & - & 9 & 1 & 13 \\
\hline & & $\%$ within local & $42.9 \%$ & - & $81.8 \%$ & $7.7 \%$ & $29 \%$ \\
\hline & \multirow{2}{*}{ Other citizens } & count & - & 12 & - & 11 & 23 \\
\hline & & $\%$ within local & - & $85.7 \%$ & - & $84.6 \%$ & $51 \%$ \\
\hline \multirow{8}{*}{ 원 } & \multirow{2}{*}{$\begin{array}{l}\text { Between } \\
25-35\end{array}$} & count & 4 & 5 & 1 & 2 & 12 \\
\hline & & $\%$ within local & $57.1 \%$ & $35.7 \%$ & $9 \%$ & $15.4 \%$ & $26,6 \%$ \\
\hline & \multirow{2}{*}{ Between 35-50 } & count & 1 & 7 & 6 & 8 & 22 \\
\hline & & $\%$ within local & $14.3 \%$ & $50 \%$ & $54.5 \%$ & $61.5 \%$ & $48,9 \%$ \\
\hline & \multirow{2}{*}{$\begin{array}{l}\text { Between } \\
50-60\end{array}$} & count & 1 & 2 & 3 & 2 & 8 \\
\hline & & $\%$ within local & $14.3 \%$ & $14.3 \%$ & $27.3 \%$ & $15.4 \%$ & $18 \%$ \\
\hline & \multirow{2}{*}{60 and above } & count & 1 & - & 1 & 1 & 3 \\
\hline & & $\%$ within local & $14.3 \%$ & & $9 \%$ & $7.7 \%$ & $6,6 \%$ \\
\hline
\end{tabular}

